\title{
FACTORS AFFECTING INFANT FORMULA FEEDING IN INFANTS AGED O-6 MONTHS IN SUKOHARJO, CENTRAL JAVA
}

\author{
Ayunda Yonik Nuralita ${ }^{1)}$, Bhisma Murti ${ }^{1,2}$, Eti Poncorini Pamungkasari²) \\ ${ }^{1)}$ Masters Program in Public Health, Sebelas Maret University \\ 2)Department of Public Health, Faculty of Medicine, Sebelas Maret University
}

\begin{abstract}
Background: Formula feeding in infants aged 0-6 months may increase the risk of morbidity and mortality. Formula feeding in Indonesia continues to increase from $15 \%$ in 2003 to $79.8 \%$ in 2013 . To the best of the authors' knowledge no studies have been done that analyzed the effects of constructs in Theory of Planned Behavior (TPB) on formula feeding practice. This study aimed to analyze the factors influencing formula feeding practice among lactating mothers for their infants aged o-6 months, using TPB constructs.

Subjects and Method: This study was an analytic observational with crosssectional approach. It was carried out in Sukoharjo District, Central Java, from April to May 2017. A sample of 150 lactating mothers were selected for this study by cluster random sampling. The exogenous variables were the role of health workers, the role of mass media, subjective norm, and maternal education. The endogenous variables were attitudes toward formula feeding, perceived behavioral control, intention, family income, maternal employment status, and formula feeding practice. The data were collected by a set of questionnaire and analyzed by path analysis.
\end{abstract}

Results: Infant formula feeding was directly affected by maternal intention $(\mathrm{b}=1.96 ; 95 \% \mathrm{CI}=0.59$ to $3.34 ; \mathrm{p}=0.005)$, perceived behavior control $(\mathrm{b}=$ $2.24 ; 95 \% \mathrm{CI}=0.79$ to $3.68 ; \mathrm{p}=0.002)$, family income $(\mathrm{b}=1.99 ; 95 \% \mathrm{CI}=0.39$ to $3.59 ; \mathrm{p}=0.014)$, and maternal employment status $(\mathrm{b}=-2.01 ; 95 \% \mathrm{CI}=-3.82$ to $-0.21 ; \mathrm{p}=0.029)$. Mother's intention was influenced by her attitude $(\mathrm{b}=$ $1.85 ; 95 \% \mathrm{CI}=0.58$ to $3.12 ; \mathrm{p}=0.004)$, subjective norm $(\mathrm{b}=2.98 ; 95 \% \mathrm{CI}=-$ 0.07 to 6.04; $\mathrm{p}=0.056)$, perceived behavior control $(\mathrm{b}=1.53 ; 95 \% \mathrm{CI}=0.44$ to 2.62; $\mathrm{p}=0.006)$, and mass media $(\mathrm{b}=2.01 ; 95 \% \mathrm{CI}=0.35$ to $3.68 ; \mathrm{p}=0.018)$. Maternal employment status was influenced by maternal education $(b=2.68$; $95 \% \mathrm{CI}=1.81$ to $3.55 ; \mathrm{p}<0.001$ ). Family income was affected by maternal employment status $(b=2.10 ; 95 \% \mathrm{CI}=1.24$ to $2.97 ; \mathrm{p}<0.001)$. Maternal attitude was influenced by the role of health personnel $(b=2.73 ; 95 \% \mathrm{CI}=$ 0.68 to $4.78 ; \mathrm{p}=0.009$ ). Likewise, maternal perceived behavior control was influenced by the role of health personnel $(b=1.03 ; 95 \% \mathrm{CI}=0.22$ to $1.84 ; \mathrm{p}=$ 0.013).

Conclusion: Infant formula feeding is directly affected by maternal intention, perceived behavior control, family income, and maternal employment status. Infant formula feeding is indirectly affected by attitude, subjective norm, and the role of health personnel.

Keywords: formula feeding, theory of planned behavior, infant

Correspondence: Ayunda Yonik Nuralita. Masters Program in Public Heath, Sebelas Maret University, Jl. Ir. Sutami 36 A, Surakarta, Central Java. Email: ayundayonik91@gmail.com. Mobile: +6285642477205. 